
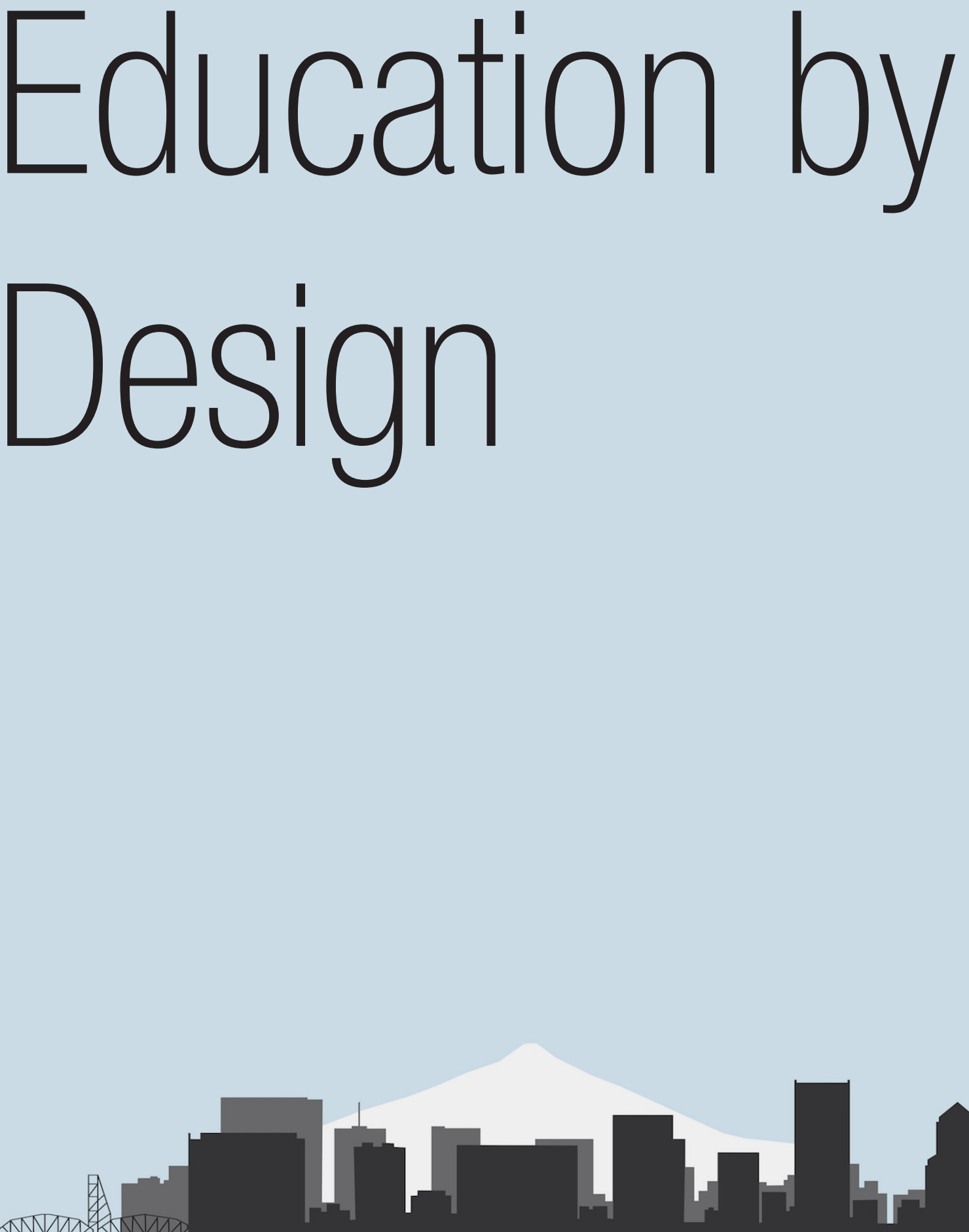

2019 Reynolds Symposium: Education by Design October 18-20, 2019 


\section{Organizing Committee:}

[co-organizers]

Professor Alison Kwok, Ph.D, FAIA, University of Oregon

Emeritus Professor John Reynolds, FAIA, University of Oregon

\section{[Symposium coordinator]}

Isabel Rivera, Ph.D., University of Oregon

Professor Walter Grondzik, P.E., Ball State University

Professor Bruce Haglund, AIA Assoc., University of Idaho

Assistant Professor Emily McGlohn, AIA, Auburn University

Associate Professor Ulrike Passe, lowa State University

Assistant Professor Siobhan Rockcastle, Ph.D., University of Oregon

Sharon Refvem, FAIA, LEED Fellow, Senior Associate and Director, Sustainability Resource Group, Hawley Peterson Snyder 


\title{
Academic Urban Labs: Architectural design studios to address local challenges.
}

\author{
Montserrat Delpino-Chamy \\ Assistant Professor \\ University of Concepción \\ Concepción, Chile \\ montserrat.delpino@gmail.com
}

\author{
María Isabel Rivera \\ Assistant Professor \\ University of Concepción \\ Concepción, Chile \\ mariaisrivera@udec.cl
}

\author{
Mabel Alarcon \\ Associated Professor \\ University of Concepción \\ Concepción, Chile \\ mabelalarcon@udec.cl
}

\begin{abstract}
Considering the complexity of ecological and social challenges, universities and the teaching of architecture offer a unique opportunity to create real-life design problems from their local communities, thereby engaging their students in the learning process. On this context, this paper presents the idea of Academic Urban Laboratories as a methodology to enhancing regional development as well as to betterprepare students for professional careers, exposing them to the benefits of holistic, integrated design outcomes.

This paper offers a review of the main challenges that the teaching of architecture currently faces, followed by a review of emerging frameworks to improve pedagogical methodologies in this discipline. A rubric to assess Academic Urban Labs' experiences is presented, which has been applied to the analysis of three architecture design studios experiences, addressing the following connections: elective course and local community, studio and local government, studio and international congress.

Finally, the main reflections are related to examining the link between academic and local stakeholders, assessing strategies to increase the efficiency of sustainable outcomes, and reducing the time demand on the management processes to support this methodology. From the results, it is possible to identify an increase in social responsibility, as well as a commitment among students towards more sustainable development, thus supporting the idea of designing new learning experiences connecting academia with real-life problems.
\end{abstract}

Keywords: Academic Urban Labs, Design Studio, Teaching Architecture, Social Responsibility 


\section{INTRODUCTION}

Universities emerge as a space of opportunity for exploring new alternatives for confronting contemporary urban problems by reinserting the knowledge produced by these institutions back into society (Aldeanueva Fernández, Ignacio; Jimenez Quintero 2013; Pizarro 2015).

During the last three decades, intense urbanization has generated an accelerated depletion of natural resources, oftentimes imposing standardized design stereotypes enabled through core knowledge. This model of growth continues spreading today with increasingly negative consequences on the ecology, economy, social ties, and quality of life, not only regional but global (Tzonis 2014b).

On this historical context, architecture has a leading role due to its ability to project and modify the built environment. Therefore, strategic approaches in the teaching of architecture can define new ways in which future architects will impact their natural and social surroundings.

Despite this potential, the teaching of architecture in many universities worldwide still does not take on the challenges presented by the current ecological crisis (Altomonte, Rutherford, and Wilson 2014; Ismail, Keumala, and Dabdoob 2017). Many architectural studios remain stuck in old practices and methodologies, weakening the relationship between academia and its territory.

This research offers a particular opportunity to reflect on new methodologies in the teaching of architecture. Its main scope is to present architectural studios as Academic Urban Laboratories and to relate pedagogical practices with real-life urban problems involving local stakeholders. This approach favors enhancing university social responsibility while reinforcing sustainable contents among architecture students.

The paper starts by reviewing the main challenges faced today in the teaching of architecture design. Then it follows the descriptions of the new pedagogical methodologies proposed by different authors from a literature review. It continues by defining architectural studios as Academic Urban Laboratories, offering a particular framework for its analysis, and by reviewing three different case studies developed in University of Concepción, Chile. Finally, it discusses the theoretical framework with the cases studies presented and concludes on a strategic process to implement and improve Academic Urban Laboratories as a design studio methodology.

\section{CHALLENGES IN THE TEACHING OF ARCHITECTURE}

Reflections regarding the quality of teaching in architecture have been present since its institutionalization in the academic curriculum, i.e., at the end of the eighteenth century (Tzonis 2014a).

Despite the current environmental crisis, the rapid urbanization of the world and the social demands emerging from these dynamics, the teaching of architecture has been slow in adapting and responding to the new urban challenges.

By reviewing published articles and the available literature, it is possible to identify different problems faced by the teaching of architecture nowadays. The following are some of the challenges hindering the development of this discipline in academia:

\section{Identifying the essential criteria in the teaching of architecture}

For María Isabel Alba, the main scope behind teaching architecture is to enable the student to learn, research, express, and organize (Alba 2016). On the other hand, Alfonso Muñoz Cosme considers that learning architecture means to learn to see, learn to think, learn to build, learn to communicate, and finally, learn to learn (Muñoz 2008). Complementarily, Haeger and del Castillo claim that teaching 
architecture, urbanism, and landscape involves a predisposition to observation, innovation, visualization, and theory-practice problem-solving processes (Haeger and del Castillo 2015).

These impressions share similarities, especially regarding observation, research, and expression. Although they also evidence different criteria with building and innovation capacities. Finally, it can also be argued that the above descriptions lack fundamental concepts which are essential in the teaching of architecture, such as creativity, projects, planning, and visualization (Dizdaroglu and Yigitcanlar 2014).

\section{Differentiation and specialization of the architectural knowledge}

The historical challenge of the architectural discipline is related to the increasing levels of specialization and division of labor in theory and practice (Tzonis 2014a). This challenge has been enhanced with the incorporation of new technologies in the design process, promoting diverse opinions among design educators, i.e., to use technology, whereas others are against it (Soliman 2017).

The difficulty emerges from the need to include all of this different architectural knowledge into the same curriculum, asking academics to incorporate both traditional and new knowledge into their classes, while teaching and producing research simultaneously. The challenge is even higher, considering the limitation of hours, space, and budget that most universities currently face (Tzonis 2014a).

\section{Design Studio Integration with the Support Subjects}

In the Architecture curriculum, Architectural Design Studios are the main subjects, demanding the highest workload of hours per week. Other subjects, such as Construction, History, Environmental Control Systems and Social Theory or Communication are supposed to offer context to serve the development of Design Studios(Ibrahim and Utaberta 2012).

Unfortunately, in practice this core subject remains often alienated from the supporting subjects. On this context, students are expected to develop design tasks without having been trained on the appropriate processes, on how to apply conceptual frameworks, or how to integrate the content acquired from other courses (Altomonte, Rutherford, and Wilson 2014).

The integration of all supporting subjects with Architectural Design Studio emerges as a requirement to combine both technical and holistic issues of sustainability.

\section{Overloaded architectural curriculum}

There has been increasing debate regarding students' workload in the university environment, as well as in the architecture discipline. This condition negatively affects the process of design studios, where teaching and learning strategies cannot be adequately implemented, particularly during short semesters or quarter systems (Soliman 2017).

Europe, as well as Chile, uses ECTS (European Credit Transfer and Accumulation System). With this nomenclature, 1 ECTS means 30 hours of work per semester. Considering that one semester implies 30 credits distributed in 16 weeks, the students require 56.25 hours of work per week [(30x30)/16], which means 11.25 hours per day, or an extra 3.25 hours over a traditional workday. This extra workload also applies to the USA and Middle East countries such as Bahrain or Qatar (Soliman 2017).

The composition of learning hours in architectural schools are 1/3 "contact hours" or direct lesson (inclass hours), while the other $2 / 3$ of the time is designated for individual or group work outside of class. Therefore, teachers may lack time to pursue different teaching methods, while students do not have sufficient time to develop holistic designs.

\section{The gap between theory and practice}

It has been assumed that the gap between theory and practice originated with the teaching of the "Arti del Disegno" in the Academia di San Luca in Rome (Tzonis 2014b). 
Many schools have tried to break this difference by bringing the studios physically onto the field, inviting outside practitioners to consult the students, or introducing a period for the student to work as an apprentice inside a professional firm (Tzonis 2014a).

Despite these methods, the gap remains between the theoretical knowledge provided by educators to students and the practical capabilities students must acquire for their future professional practice (Charalambous and Christou 2016).

\section{EMERGING FRAMEWORKS IN THE TEACHING OF ARCHITECTURE}

Despite all these historical challenges, new proposals are taking on the architectural agenda today, offering alternative methodologies to update the academic dimension of this discipline.

The global environmental crisis is unquestionable. According to the report "Hot Cities: battle-ground for climate change" from the United Nations Human Settlement Program (UN-HABITAT), cities contribute up to $70 \%$ of greenhouse-gas emissions. Therefore, architects have an enormous responsibility for the future of our planet.

In this context, many International Institutions are offering guidance to include the teaching of sustainability in the architectural curriculum. Some examples can be found in: The Decade of Education for Sustainable Development 2004-2014 (UN), Better Life Index 2010 (OCDE), Sustainable Hub 2011 (RIBA), Environmental Design in University Curricula and Architectural Training in Europe, 2012 (EDUCATE), and International Conferences on Sustainable Architecture (Haeger and del Castillo 2015).

Teaching sustainability requires increasing the students' awareness towards social responsibility. This concept of University Social Responsibility (hereafter USR), emerged during the first decade of the twenty-first century, evidencing the need to educate professionals with a greater sense of social commitment towards their society.

The University Social Responsibility approach has been reinforced by supranational entities, such as United Nations Educational, Scientific and Cultural Organization (hereafter UNESCO) and the OEI, promoting a space of higher learning to serve the needs of local territories (Martí Noguera, Moncayo, and Martí-Vilar 2016). Other initiatives can be found in The Assessment Instrument for Sustainability in Higher Education (AISHE) by the Dutch organization DHO, The Higher Education Partnership for Sustainability of the United Kingdom, The New Jersey Higher Education Partnership for Sustainability, the Project "Responsible Universities" in Spain (Aldeanueva Fernández, Ignacio; Jimenez Quintero 2013), and the "University Builds Country" project in Chile. All of these programs promote the incorporation of sustainability and social responsibility approaches in universities (Delpino-Chamy and Rivera 2017).

\section{NEW SOCIAL INTEGRATED TOOLS FOR ARCHITECTURAL DESIGN STUDIOS}

Historically, architecture studios have gone through different phases. From physically centered results during the 1960 s and 1970 s, then passing through a socially centered phase during the 1980 s, and finally towards a hybrid approach at the beginning of 2000. This later stage proposes to refocus the architectural studios on the practical aspects of the discipline (Grant Long 2012).

This change has allowed taking into consideration not only what is expected to be taught, but also how it will be taught (Alba 2016).

Following this approach, some authors have proposed the idea of Social Laboratories as a space of experimentation within the architectural studio, where academics and community get together with the 
purpose of analyzing and resolving local problems through mutual collaboration (Bolaño and Aguilera 2014).

The idea of Social Laboratories is presented as a Service-Based Learning methodology, associated with the University Social Responsibility framework, offering an opportunity to put university knowledge at the service of local communities (Univ. de la Frontera, UC Valparaiso, Univ. de Talca \& Univ. Concepción 2010).

Under the Service-Based Learning approach, it is possible to move away from a traditional teaching model, in which the educator transmits the knowledge to the student, towards a competency-based model, offering students diverse learning experiences in which they become the protagonists of their academic training (Alba 2016).

\section{DESIGN STUDIOS AS ACADEMIC URBAN LABS}

After reviewing the challenges of the teaching of architecture today, and with the emergence of sustainability and university social responsibility frameworks, the need to link more strongly the educational sector with parallel initiatives in the professional domain is quite evident (Altomonte et al. 2014).

To do so, Tzonis proposes to face this challenge by rescuing some methodologies adopted by one of the oldest professions: the academic hospital. Under this approach, "the gap between theory and practice is closed by working on real-life cases, real-life design commissions, as in academic hospitals where real patients and not dummy patients, are treated" (Tzonis 2014a, 2).

Linking Design Studios with real-life problems has been shared and analyzed by many authors in the literature (Bolaño and Aguilera 2014; Tzonis 2014a; Pizarro 2015; Alba 2016; Charalambous and Christou 2016). The arguments are generally based on the hypothesis that when the challenge involves the application of knowledge to a practical and socially useful task, students become more engaged in their learning experience and process (Leroy et al. 2001; Kolb and Kolb 2005 in Altomonte, Rutherford, and Wilson 2014).

This idea is defined as a Problem-based learning methodology; also associated with University Social Responsibility framework (Univ. de la Frontera, UC Valparaiso, Univ. de Talca \& Univ. Concepción 2010). This methodology involves a pragmatic training possibility for students to develop skills required to solve grounded problems. Complementarily, it offers chances to increase university-local stakeholders alliances and contributes to the sustainable development of local surroundings. It can be a successful way to increase knowledge, contribute to local development, strengthen university networks, and increase the level of students' interest towards new learning experiences that are more connected with real-life problems and stakeholders.

This exploration comes aligned with ideas applied in the University of Cyprus, committed to the vision that "Students today should be encouraged not only to develop their design thinking, but to develop it 'responsibly' towards others and the environment. They should also be encouraged to develop management and collaborative skills, in order to handle all different variables and stakeholders in their process of designing" (Charalambous and Christou 2016). Other similar international examples are presented by Pizarro (Pizarro 2015); reviewing master plan proposals produced by Universities-Public Institution alliances in Colombia, China, and Germany.

Hence, Academic Urban Labs can be understood as a methodology that relates pedagogical practices with real-life urban problems, involving local stakeholders, and contributing to the sustainable development of local surroundings. 
The dynamics emerging from the Urban Labs approach had been described in previous research (Delpino-Chamy and Rivera 2017), and consider the following steps:

- Identify an urban problem.

- Explore and design proposals at complementary scales: urban-scale and architectural project-scale.

- Build local alliances between different stakeholders.

- Strength social capital at local surroundings.

\section{DESCRIBING AND ASSESSING URBAN LABS EXPERIENCES}

In order to analyze each case study, a methodological framework has been generated based on Bolaño \& Aguilera (2017) "Analysis of social laboratories,"1 and Dominguez (2009) processes for University Social Responsibility ${ }^{2}$. Some main considerations regarding the Architectural Design Process, defined by Soliman (2017), have also been included.

With these considerations, a rubric is proposed, to describe and assess experiences related to Academic Urban Laboratories (see table 1).

Table 1 - Rubric to assess Academic Urban Labs experiences

\begin{tabular}{|c|c|c|c|}
\hline & LOW & MEDIUM & HIGH \\
\hline \multicolumn{4}{|l|}{ MANAGEMENT } \\
\hline \begin{tabular}{l|l} 
Objective \\
\end{tabular} & $\begin{array}{l}\text { Objectives were } \\
\text { independent of local } \\
\text { problems }\end{array}$ & $\begin{array}{l}\text { Objectives were related } \\
\text { to local problems }\end{array}$ & $\begin{array}{l}\text { Objectives were aligned } \\
\text { with local problems }\end{array}$ \\
\hline Stakeholders & $\begin{array}{l}\text { Local alliances were } \\
\text { built }\end{array}$ & $\begin{array}{l}\text { Local alliances were } \\
\text { built }\end{array}$ & $\begin{array}{l}\text { Local alliances were } \\
\text { built }\end{array}$ \\
\hline $\begin{array}{l}\text { Institutional } \\
\text { Strategy }\end{array}$ & $\begin{array}{l}\text { Plenty of time and } \\
\text { resources were } \\
\text { demanded }\end{array}$ & $\begin{array}{l}\text { Some time and } \\
\text { resources were } \\
\text { demanded }\end{array}$ & $\begin{array}{l}\text { Little time and few } \\
\text { resources were } \\
\text { demanded }\end{array}$ \\
\hline \multicolumn{4}{|l|}{ TEACHING } \\
\hline \begin{tabular}{l|l} 
Methodological \\
Implementation
\end{tabular} & $\begin{array}{l}\text { Requires a lot of } \\
\text { planning and } \\
\text { preparation }\end{array}$ & $\begin{array}{l}\text { Requires moderate } \\
\text { planning and } \\
\text { preparation }\end{array}$ & $\begin{array}{l}\text { Requires low planning } \\
\text { and preparation }\end{array}$ \\
\hline $\begin{array}{l}\text { Architectural } \\
\text { Design Processes }\end{array}$ & $\begin{array}{l}\text { Few processes and } \\
\text { poor pedagogical } \\
\text { results }\end{array}$ & $\begin{array}{l}\text { Some processes involved } \\
\text { and acceptable } \\
\text { pedagogical results }\end{array}$ & $\begin{array}{l}\text { Diversity of processes } \\
\text { and effective } \\
\text { pedagogical results }\end{array}$ \\
\hline \multicolumn{4}{|l|}{ RESEARCH } \\
\hline \begin{tabular}{|l|l|} 
& Conferences \\
\end{tabular} & Not attended & $\begin{array}{l}\text { Attend a national } \\
\text { conference }\end{array}$ & $\begin{array}{l}\text { Attend an international } \\
\text { conference }\end{array}$ \\
\hline Publication & $\begin{array}{l}\text { No documents were } \\
\text { published }\end{array}$ & $\begin{array}{l}\text { Low-impact } \\
\text { publications }\end{array}$ & $\begin{array}{l}\text { Medium to high- } \\
\text { impact publications }\end{array}$ \\
\hline \multicolumn{4}{|l|}{ OUTREACH } \\
\hline Media Reach & $\begin{array}{l}\text { The experience was } \\
\text { not covered }\end{array}$ & Appear in local media & $\begin{array}{l}\text { Appear in national or } \\
\text { regional media }\end{array}$ \\
\hline Social Reach & $\begin{array}{l}\text { No impacts in local } \\
\text { communities }\end{array}$ & $\begin{array}{l}\text { The local community } \\
\text { was engaged. Life } \\
\text { standards were not } \\
\text { improved }\end{array}$ & $\begin{array}{l}\text { Local communities } \\
\text { were engaged. Living } \\
\text { standards improved }\end{array}$ \\
\hline
\end{tabular}

\footnotetext{
${ }^{1}$ Objective - Responsible - Stakeholders - Process and Implementation - Outreach
}

${ }^{2}$ Management - Teaching - Research - Outreach 
Following this rubric, three case studies will be presented and analyzed. The first case study presents a local alliance, continuing with a regional partnership, to end up analyzing and presenting an example of international academic urban lab.

Figure 1: Case Study 1

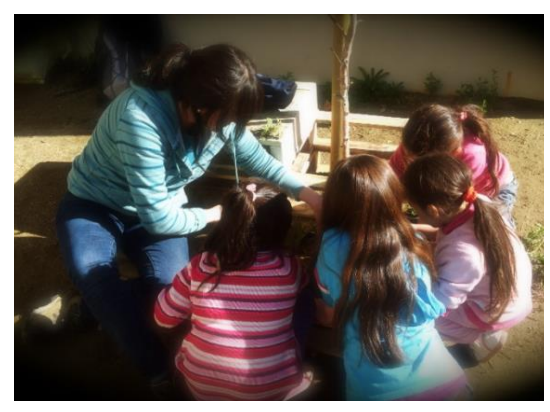

Figure 2: Case Study 2

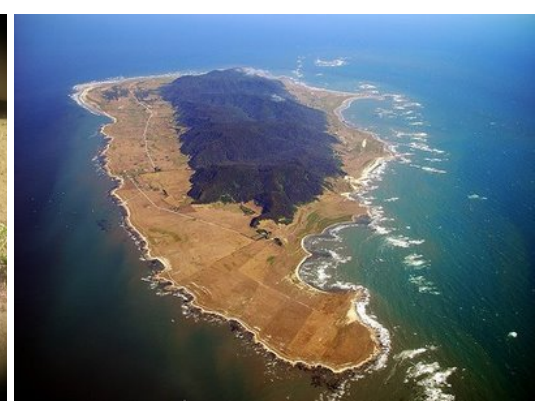

Figure 3: Case Study 3

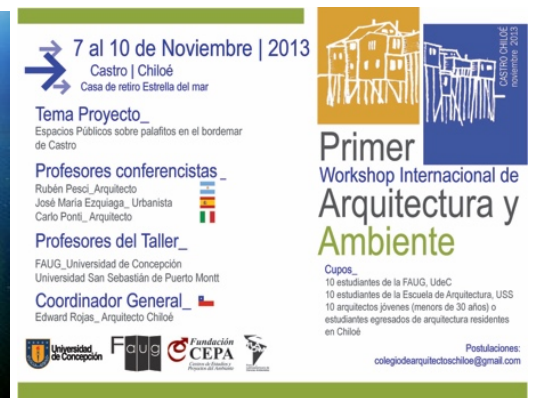

Case Study 1: elective course \& local community

Management

- Objective: Improve the built environment of local communities by applying sustainable design principles.

- Stakeholders: The request was self-generated. For its implementation, the national NGO "TECHO" incorporated, and a local community got involved in the project.

- Institutional Strategy: An elective course was created, named "RRR: Recycle, Reinterpret, Rehabilitate." The course was open for students coming from Architecture, Geography and Environmental Engineering. The implementation of a recycling center was created inside the facilities to collect recycled food-related containers as well as other reclaimed construction materials (i.e., pallets, automobile wheels, wood). These materials were used to regenerate community public spaces.

Teaching

- Methodological Implementation: This course was designed based on the University Social Responsibility theoretical framework. It began with an introductory theoretical session presenting sustainable principles. It considered material exploration, a design process that included: defining the problem, brainstorming and analyzing, collecting information and materials, developing solutions, participatory design, building, and presenting solutions in an inauguration event. The assessment included peer-review and course evaluation.

- Architectural Design Process: included site visits, experimental learning, interdisciplinary teamwork, group discussions, realistic design problem, physical modeling, integration of a building into the landscape.

$\underline{\text { Research }}$

- Conferences: The results of this experience were presented in two conferences. Congress of Architecture and Environment (CAA), Conference Who cares for Chilean cities? Academic answers from architecture, public space, and urban projects, and ARCC 2017 Architecture of Complexity: design, systems, society, and environment.

- Publication: no paper or book was published from this work.

Outreach

- Media: The experience was covered by the university local press, through television, and by local radio stations for the community.

- Social: The public space of the local community was improved for a particular time. Inhabitants participated from the design-build process. Participatory activities with local communities were carried out. 


\section{Case Study 2: design studio \& local government}

\section{$\underline{\text { Management }}$}

- Objective: The objective of the assignment was to design a masterplan and a community center for two (2) isolated settlements in the south of Chile (Mocha Island and Tirua)

- Stakeholders: The request came from a regional government agency (SUBDERE). Its development involved Municipal technicians and local architecture schools.

- Institutional Strategy: The Faculty chose to assign the request to medium and advanced undergraduate studios (in their third and fourth year), during one semester. Resources were made available for field trips.

\section{Teaching}

- Methodological Implementation: The assignment addressed a multiscale and multidisciplinary approach. The work started with a systemic territorial diagnostic evaluation, later verifying onsite. Students developed a masterplan proposal, including in each a community center. Municipal technicians and professionals from other disciplines were invited into the studios to offer theoretical and practical knowledge.

- Architectural Design Process: The design process considered identifying realistic design problems, site visits, group discussions, interdisciplinary teamwork, sketching, physical modeling, Research the use of technology, and strategies to integrate the buildings into the landscape.

- Conferences: not presented

- Publication: The book "Alianzas Estratégicas para el desarrollo integrado de territories aislados" Outreach Was published with the support of regional government (SUBDERE) in 2013.

- Media: The results of the experience were displayed at the Regional Government Building. The local press covered this presentation.

- Social: Although local inhabitants were interviewed during the diagnostic stage, the local community was not involved in the planning process, and the designed proposals have not been built.

\section{Case Study 3: vertical studio \& international conference}

\section{Management}

- Objective: Was to develop a master plan in collaboration with local stakeholders to regenerate the waterfront of Castro ${ }^{3}$ on the island of Chiloe.

- Stakeholders: The request came from the organizing committee of the Fifth International Conference on Architecture and the Environment, supported by 45 several foundations (Spanish abbreviation CEPA) as a way to outreach conference participants with the local community through post-conference activity. The workshop organizing committee included the Architects Association of Chiloe, the Housing and Urbanism Service (SERVIU) and the two undergraduate programs of architecture in southern Chile. As a result, the activities included the participation of students from two different undergraduate programs, keynote speakers from the international conference, and local practitioners from government agencies, as well as the national design award winner, architect Edward Rojas.

- Institutional Strategy: A vertical studio was developed for students for one undergraduate program from junior year. The studio worked under the principals of the Fifth International Conference on Architecture and Environment, in an International Workshop for a three-day weekend, in the southern island of Chiloe.

\footnotetext{
${ }^{3}$ A city in southern Chile

${ }^{4}$ Latin American Faculties of Environmental Science

5 The Center for Environmental Studies and Projects
} 
Teaching

- Methodological Implementation: The participants on the vertical studio were selected according to their academic records and personal motivation. The studio started with the diagnostic of local urban problems, followed by the design of a masterplan (urban-scale) proposal, presented and improved during the International Workshop conducted in Chiloe. The masterplan constituted the base for each student's architectural design project (building-scale). For the realization of the studio, two field trips were conducted.

- Architectural Design Process included: practical design problem, site visits, discussion and critical reviews from renowned architects, interdisciplinary teamwork, group discussions, experimental learning, integrated design strategies to respond to the landscape and local weather conditions, Research use of technology, sketching, and physical modeling.

- Conferences: The result of this experience was presented at the PLEA 2017 Conference in Edinburgh, Design to Thrive.

Outreach

- Publication: The paper was published in the conference proceeding.

- Media: Regional media covered the experience, both in Concepción and Castro, University press and radio, and it was also promoted in the website of the International Conference.

- Social: Local professionals from the southern part of Chile participated in the International Workshop, as well as keynote speakers, practitioners from the local government institution, and students from two undergraduate programs.

\section{MAIN FINDINGS}

Academic methodologies of Urban Labs experiences are compared and evaluated under different factors, according to the same rubric previously presented.

Table 2 - Comparative Analysis of three case studies

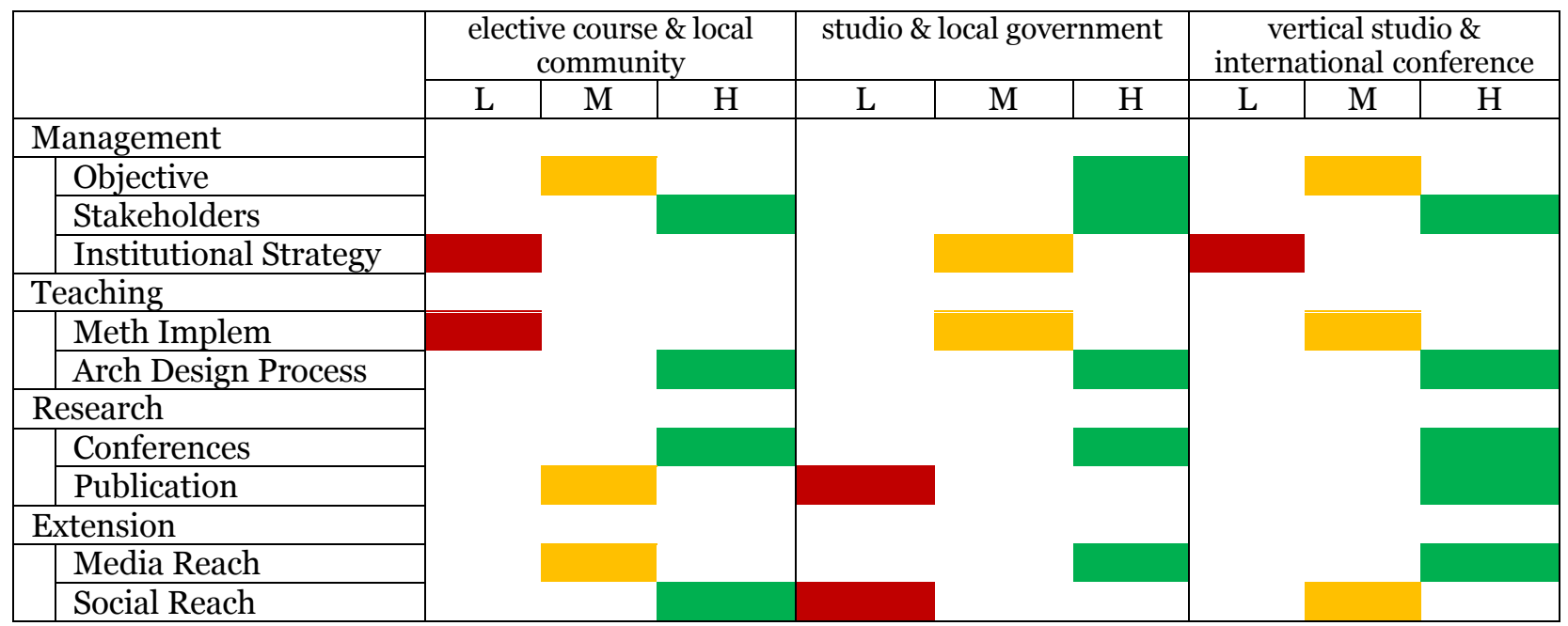

Key of colors: red is low, yellow is medium and green is high.

From this comparative analysis presented in Table 2, it is possible to identify that:

1. Alliances with governmental institutions guarantee an alignment with local needs and objectives while reducing the amount of time and resources needed from the university.

2. Working with the community demands more time; however, it guarantees better social outcomes.

3. Working in studios as Urban Labs have proven to be highly effective for architectural design outcomes. 
4. Relation with other academic institutes or international foundations increases the level of effectiveness, and eventually it could contribute to enhancing research and learning outcomes, particularly for students who generally do not get such experiences in their academic career.

\section{CONCLUSIONS}

The research has been able to systematize three significant experiences regarding new methodological approaches emerging from experiences of the southern Latin-American world, at the University of Concepcion, Chile. These experiences proposed the idea of Academic Urban Labs as an Architectural Studio methodology. The main objective is to relate pedagogical practices with real-life urban problems, involving local stakeholders, and contributing to the sustainable development of local surroundings.

The literature reviewed for this paper supports the effectiveness of the Academic Urban Labs approach, relating it with new learning experiences (Alba 2016), including diverse, sustainable approaches (Altomonte et al. 2014, Haeger \& del Castillo 2015), and training student with real-life design problems (Bolaños \& Aguilera 2014, Tzonis, 2014, Pizarro 2015).

However, the proposed methodology also evidenced some difficulties, particularly regarding the amount of time demanded for the planning and implementations of Academic Urban Labs initiatives. However, enhancing alliances with governmental or other universities can contribute to reducing the time demanded, while improving the outreach of the project.

Further research is recommended to improve Academic Urban Labs by comparing the results of these exploratory methodologies in relation to some traditional studio teaching practices. Also, it should be recommended to review other case studies that already exist, such as the Chinese experiences, where "design institutes, attached to schools of architecture can deliver products of high professional quality, employing professors and several selected students" (Tzonis, 2014, p.3)

As described in previous research, this experience presents as a new strategy to move from the old 'University Extension', to a new holistic model of University for Social Responsibility (Delpino-Chamy \& Rivera 2017), promoting inter solidarity between citizens, alliances with external actors and the creation of new learning communities (Dominguez 2009).

Moreover, even though all the presented design ideas have not been able to get built or materialized yet, it can be said that the three projects significantly increased the awareness and knowledge of sustainability concepts for both communities and the universities involved, with a similar experience noted by Pizarro (2015, p.9).

Academic Urban Labs allow relating different specialization of architectural knowledge as well, since it could help to reduce the workload in the architectural curriculum by mainly reducing the gap between theory and practice.

\section{REFERENCES}

Alba, María Isabel. 2016. 'La Enseñanza de La Arquitectura. Iniciación Al Aprendizaje Del Proyecto Arquitectónico'. Revista Española de Pedagogía, no. 265: 444.

Aldeanueva Fernández, Ignacio; Jimenez Quintero, José Antonio. 2013. 'Experiencias Internacionales En Materia de Responsabilidad Social Universitaria'. Visión de Futuro 17 (1): 1-16.

Altomonte, Sergio, Peter Rutherford, and Robin Wilson. 2014. 'Mapping the Way Forward: Education for Sustainability in Architecture and Urban Design'. Corporate Social Responsibility and Environmental Management 21 (3): 143-54. https://doi.org/10.1002/csr.1311.

Bolaño, Alvaro, and Fabián Aguilera. 2014. 'Caracterización Del Modelo de Aprendizaje a Partir de Laboratorios de Diseño Con Énfasis En Factores Sociales'. Revista de Arquitectura. 
https://doi.org/10.41718/RevArq.2014.16.1.4.

Charalambous, Nadia, and Natasa Christou. 2016. 'Re-Adjusting the Objectives of Architectural Education'. Procedia - Social and Behavioral Sciences 228 (June): 375-82. https://doi.org/10.1016/j.sbspro.2016.07.056.

Delpino-Chamy, Montserrat, and Maria Isabel Rivera. 2017. 'Architectural Design Studio as a Tool to Promote University Social Responsibility (USR) in the Improvement of Urban Environments'. In Design to Thrive, 2259-67.

Dizdaroglu, Didem, and Tan Yigitcanlar. 2014. 'A Parcel-Scale Assessment Tool to Measure Sustainability through Urban Ecosystem Components : The MUSIX Model'. Ecological Indicators 41: 115-30. https://doi.org/10.1016/j.ecolind.2014.01.037.

Grant Long, Judith. 2012. 'State of the Studio Revisiting the Potential of Studio Pedagogy in U.S.-Based Planning Programs'. Journal of Planning Education and Research 32: 431-48. https://doi.org/10.1177/0739456X12457685.

Haeger, Claudia Castillo, and Mario del Castillo. 2015. 'ENSEÑANZA, SUSTENTABILIDAD, ARQUITECTURA'. Arquitecturas Del Sur 33: 30-43.

Ibrahim, Nik Lukman Nik, and Nangkula Utaberta. 2012. 'Learning in Architecture Design Studio'. Procedia - Social and Behavioral Sciences 60 (Figure 1): 30-35. https://doi.org/10.1016/j.sbspro.2012.09.342.

Ismail, Muhammad Azzam, Nila Keumala, and Rawia Marwan Dabdoob. 2017. 'Review on Integrating Sustainability Knowledge into Architectural Education: Practice in the UK and the USA'. Journal of Cleaner Production 140: 1542-52. https://doi.org/10.1016/j.jclepro.2016.09.219.

Martí Noguera, Juanjo, Jorge Eduardo Moncayo, and Manuel Martí-Vilar. 2016. 'Revisión De Propuestas Metodológicas Para Evaluar La Responsabilidad Social Universitaria’. Revista Digital de Investigación En Docencia Universitaria, no. 1: 77. https://doi.org/10.19083/ridu.8.364.

Pizarro, Rafael E. 2015. 'Challenges of Implementing Sustainable Urban Design Plans through Community-University Partnerships: Lessons from Colombia, China, and Germany'. Current Opinion in Environmental Sustainability 17: 48-56. https://doi.org/10.1016/j.cosust.2015.11.005.

Soliman, Ashraf M. 2017. 'Appropriate Teaching and Learning Strategies for the Architectural Design Process in Pedagogic Design Studios'. Frontiers of Architectural Research 6 (2): 204-17. https://doi.org/10.1016/j.foar.2017.03.002.

Tzonis, Alexander. 2014a. 'A Framework for Architectural Education'. Frontiers of Architectural Research 3 (4): 477-79. https://doi.org/10.1016/j.foar.2014.10.001.

-- . 2014b. 'Architectural Education: The Core and the Local'. Frontiers of Architectural Research 3 (2): 224-26. https://doi.org/10.1016/j.foar.2014.04.001.

Univ. de la Frontera, UC Valparaiso, Univ. de Talca \& Univ. Concepción, MECESUP UCO 0714. 2010. 'Modelo Educativo Para La Enseñanza de La Responsabilidad Social'. 